This item was submitted to Loughborough's Research Repository by the author.

Items in Figshare are protected by copyright, with all rights reserved, unless otherwise indicated.

\title{
Generation and loss of reactive oxygen species in low-temperature atmospheric-pressure $\mathrm{RF} \mathrm{He}+\mathrm{O} 2+\mathrm{H} 2 \mathrm{O}$ plasma
}

PLEASE CITE THE PUBLISHED VERSION

http://dx.doi.org/10.1109/PLASMA.2012.6383299

PUBLISHER

IEEE

VERSION

AM (Accepted Manuscript)

\section{PUBLISHER STATEMENT}

This work is made available according to the conditions of the Creative Commons Attribution-NonCommercialNoDerivatives 4.0 International (CC BY-NC-ND 4.0) licence. Full details of this licence are available at: https://creativecommons.org/licenses/by-nc-nd/4.0/

\section{LICENCE}

CC BY-NC-ND 4.0

\section{REPOSITORY RECORD}

McKay, Kirsty, Ding-Xin Liu, Ming-Zhe Rong, Felipe Iza, and Michael G. Kong. 2019. "Generation and Loss of Reactive Oxygen Species in Low-temperature Atmospheric-pressure RF He+o2+h2o Plasma". figshare. https://hdl.handle.net/2134/16408. 


\title{
GENERATION AND LOSS OF REACTIVE OXYGEN SPECIES IN LOW- TEMPERATURE ATMOSPHERIC-PRESSURE RF HE $+\mathrm{O}_{2}+\mathrm{H}_{2} \mathrm{O}$ PLASMA
}

\author{
K McKay ${ }^{1}$, D X Liu ${ }^{2}$, M Z Rong ${ }^{2}$, F Iza ${ }^{1}$ and M G Kong ${ }^{1,2}$ \\ ${ }^{1}$ School of Electronic, Electrical and Systems Engineering, Loughborough University, UK \\ ${ }^{2}$ State Key Laboratory of Electrical Insulation \& Power Equipment, Xi'an Jiaotong University, \\ China
}

This study focuses on the generation and loss of reactive oxygen species (ROS) in lowtemperature atmospheric-pressure rf $(13.56 \mathrm{MHz}) \mathrm{He}+\mathrm{O}_{2}+\mathrm{H}_{2} \mathrm{O}$ plasmas, which are of interest for many biomedical applications. Pure $\mathrm{He}+\mathrm{O}_{2}$ plasmas are a good source of ozone, singlet oxygen and atomic oxygen, with densities of these species increasing as oxygen content increases ${ }^{1}$. $\mathrm{He}+\mathrm{H}_{2} \mathrm{O}$ plasmas offer an interesting alternative to $\mathrm{He}+\mathrm{O}_{2}$ plasmas as a source of reactive oxygen species (ROS), and they produce significant amounts of hydrogen peroxide, hydroxyl radicals and hydroperoxyl radicals, which increase with increasing water content ${ }^{2}$. Admixtures of $\mathrm{O}_{2}$ and $\mathrm{H}_{2} \mathrm{O}$ lead to richer cocktails of $\mathrm{ROS}$ that combine all these species.

By means of 1-dimensional fluid simulations (61 species, 878 reactions), the key ROS and their generation and loss mechanisms are identified as a function of the oxygen and water content in the feed gas. Identification of the main chemical pathways can guide the optimization of $\mathrm{He}+\mathrm{O}_{2}+\mathrm{H}_{2} \mathrm{O}$ plasmas for the production of particular ROS.

For a given oxygen concentration, the presence of water in the feed gas decreases the net production of oxygen-derived ROS, while for a given water concentration, the presence of oxygen enhances the net production of water-derived ROS.

The optimum discharge conditions would depend on the actual application but the general trend is that a higher density of ROS is obtained at low water concentration and cocktails with higher oxidation potential at high water concentrations.

Although most ROS can be generated in a wide range of oxygen and water admixtures, the chemical pathways leading to their generation change significantly as a function of the feed gas composition. Therefore, care must be taken when selecting reduced chemical sets to study these plasmas.

1. D.X. Liuet al. "Main Species and Physicochemical Processes in Cold Atmospheric-pressure He+O2 Plasmas", Plasma Process. Polym., vol. 7, pp. 846, 2010.

2. D. X. Liu et al."Global model of low-temperature atmospheric-pressure $\mathrm{He}+\mathrm{H} 2 \mathrm{O}$ plasmas", Plasma Sources Sci. Technol., vol. 19, pp. 025018, 2010.

\footnotetext{
* This work was supported by the Engineering Physical Science Research Council (EPSRC) of UK
} 